\title{
Case report of a 'relatively' new corneal disease
}

\begin{tabular}{|c|c|}
\hline \multicolumn{2}{|c|}{$\begin{array}{l}\text { Authors: } \\
\text { Dirk J. Booysen } 1 \text { (1) } \\
\text { Roland Höllhumer }\end{array}$} \\
\hline \multicolumn{2}{|c|}{$\begin{array}{l}\text { Affiliations: } \\
{ }^{1} \text { Department of Optometry, } \\
\text { Faculty of Health Sciences, } \\
\text { University of Johannesburg, } \\
\text { Johannesburg, South Africa }\end{array}$} \\
\hline \multicolumn{2}{|c|}{$\begin{array}{l}\text { 2Department of } \\
\text { Ophthalmology, University } \\
\text { of the Witwatersrand } \\
\text { Johannesburg, Johannesburg, } \\
\text { South Africa }\end{array}$} \\
\hline \multicolumn{2}{|c|}{$\begin{array}{l}{ }^{3} \text { The Cornea Foundation, } \\
\text { Johannesburg, South Africa }\end{array}$} \\
\hline \multicolumn{2}{|c|}{$\begin{array}{l}\text { Corresponding author: } \\
\text { Roland Hollhumer, } \\
\text { hollhumer@gmail.com }\end{array}$} \\
\hline \multicolumn{2}{|c|}{$\begin{array}{l}\text { Dates: } \\
\text { Received: } 28 \text { Oct. } 2019 \\
\text { Accepted: } 17 \text { Jan. } 2020 \\
\text { Published: } 05 \text { Mar. } 2020\end{array}$} \\
\hline \multicolumn{2}{|c|}{$\begin{array}{l}\text { How to cite this article: } \\
\text { Booysen DJ, Höllhumer R. } \\
\text { Case report of a 'relatively' } \\
\text { new corneal disease. Afr } \\
\text { Vision Eye Health. 2020;79(1), } \\
\text { a543. https://doi.org/ } \\
\text { 10.4102/aveh.v79i1.543 }\end{array}$} \\
\hline \multicolumn{2}{|c|}{$\begin{array}{l}\text { Copyright: } \\
\text { (c) 2020. The Author(s) } \\
\text { Licensee: AOSIS. This v } \\
\text { is licensed under the } \\
\text { Creative Commons } \\
\text { Attribution License. }\end{array}$} \\
\hline \multicolumn{2}{|l|}{ Read online: } \\
\hline 回骂回 & $\begin{array}{l}\text { Scan this QR } \\
\text { code with your } \\
\text { smart phone or } \\
\text { mobile device } \\
\text { to read online. }\end{array}$ \\
\hline
\end{tabular}

Peripheral hypertrophic sub-epithelial corneal degeneration was first described in 2003 and involves bilateral, symmetrical, peripheral, hypertrophic and sub-epithelial corneal opacification. The disease affects mostly young white women with light-coloured eyes and must be differentiated from corneal intraepithelial neoplasia, bullous keratopathy, climatic droplet keratopathy, corneal amyloidosis, corneal keloid, hereditary hypertrophic scarring, pseudo-pterygia and Salzmann's nodular degeneration. This case report serves to highlight the clinical findings.

Keywords: corneal opacification; sub-epithelial; degeneration; hypertrophic; cornea.

A 41-year-old white woman presented for a routine examination. Her main complaints were photophobia and poor vision. Examination revealed the following refraction:
R. $+1.00 /-1.75 \times 110 \quad 6 / 7.5$
L. $+0.50 /-1.25 \times 80 \quad 6.7 .5$

Intraocular pressure was $16 \mathrm{mmHg}$ in both right and left eyes, and the crystalline lenses were clear. Fundoscopy revealed no retinal or posterior segment pathology. Slit lamp examination revealed bilateral inferior sub-epithelial, fairly symmetrical, vascularised hypertrophic corneal opacification (Figure 1). Pentacam scan showed changes in the inferior cornea extending well into the stroma (Figure 2). Optical coherence tomography confirmed stromal invasion in both eyes (Figure 3).

A diagnosis of peripheral hypertrophic sub-epithelial corneal degeneration (PHSCD) was made. Peripheral hypertrophic sub-epithelial corneal degeneration was first described in 2003 by Maust and Raber ${ }^{1}$ and involves bilateral, symmetrical, peripheral, hypertrophic and sub-epithelial corneal opacification. Adjacent limbal vascularisation is not uncommon, but chronic ocular surface inflammation is usually absent. ${ }^{2}$ An increase in hyperopic astigmatism as a result of the disease may cause blurred vision which with ocular irritation is the most common presenting symptoms. ${ }^{3}$ The disease affects mostly young white women with light-coloured eyes and must be differentiated from corneal intraepithelial neoplasia, bullous keratopathy, climatic droplet keratopathy, corneal amyloidosis, corneal keloid, hereditary hypertrophic scarring, pseudo-pterygia and Salzmann's nodular degeneration. ${ }^{2,4}$ Salzmann's nodular degeneration is often asymptomatic, unilateral, mid-peripheral and associated with chronic ocular surface inflammation. ${ }^{5}$ Underlying causes of Salzmann's degeneration include phlyctenular keratitis, Meibomian gland dysfunction, contact lens wear, peripheral neovascularisation, pterygium, keratoconjunctivitis sicca and exposure keratoconjunctivitis. ${ }^{6}$

Histologic findings of PHSCD show a conjunctival component similar to that of pterygium and a corneal component with hypocellular fibrous tissue similar to that seen in Salzmann's nodular degeneration - in other words, the disease can be described as pterygium-like with a corneal component. $^{2}$

Most patients require no therapeutic intervention other than frequent use of lubricants. In those patients with significant discomfort and where the visual axis is threatened, superficial keratectomy with pterygium excision and conjunctival autograft can be performed. ${ }^{2}$

The patient described in the case report was referred for surgical opinion, but because of lack of visual involvement, the surgeon suggested conservative therapy with lubrication as the best course of action, provided that she has regular follow-up to monitor progression. 


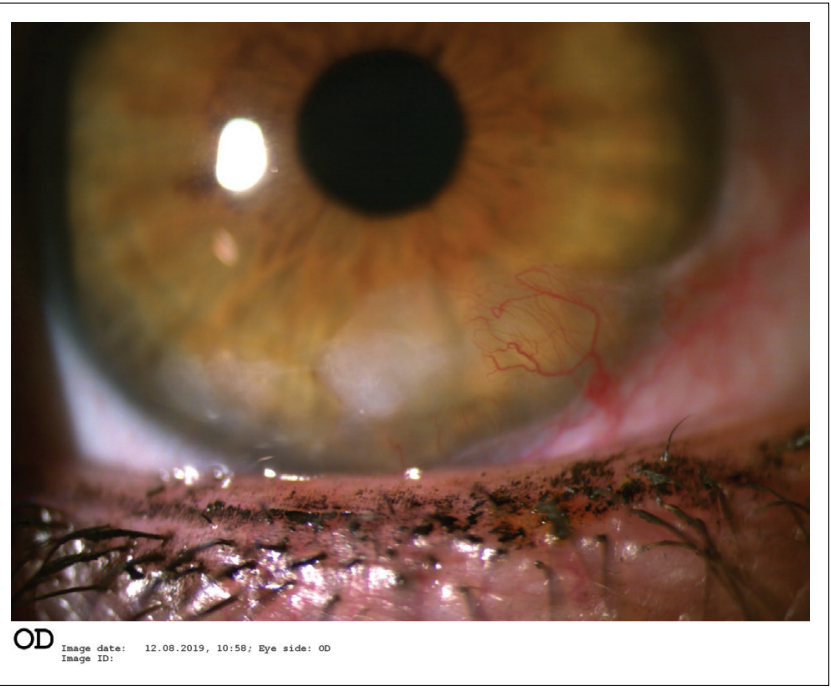

Source: Photo courtesy of Dirk J. Booysen.

$\mathrm{OD}$, Oculus dexter.

FIGURE 1: Right eye showing corneal opacification and vascularisation.

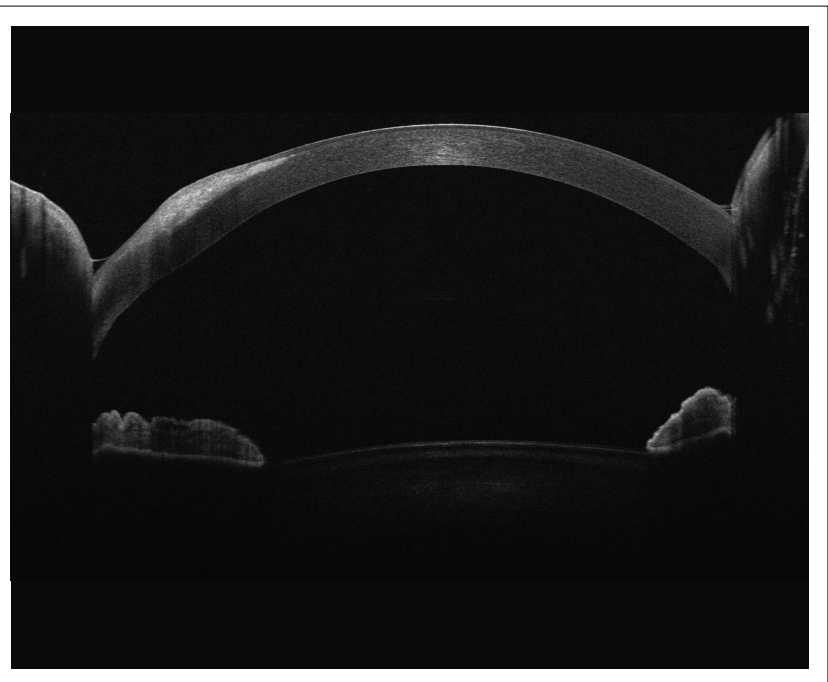

Source: Image courtesy of Dirk J. Booysen.

FIGURE 3: Anterior segment optical coherence tomography showing extent and depth of lesion in the right eye.

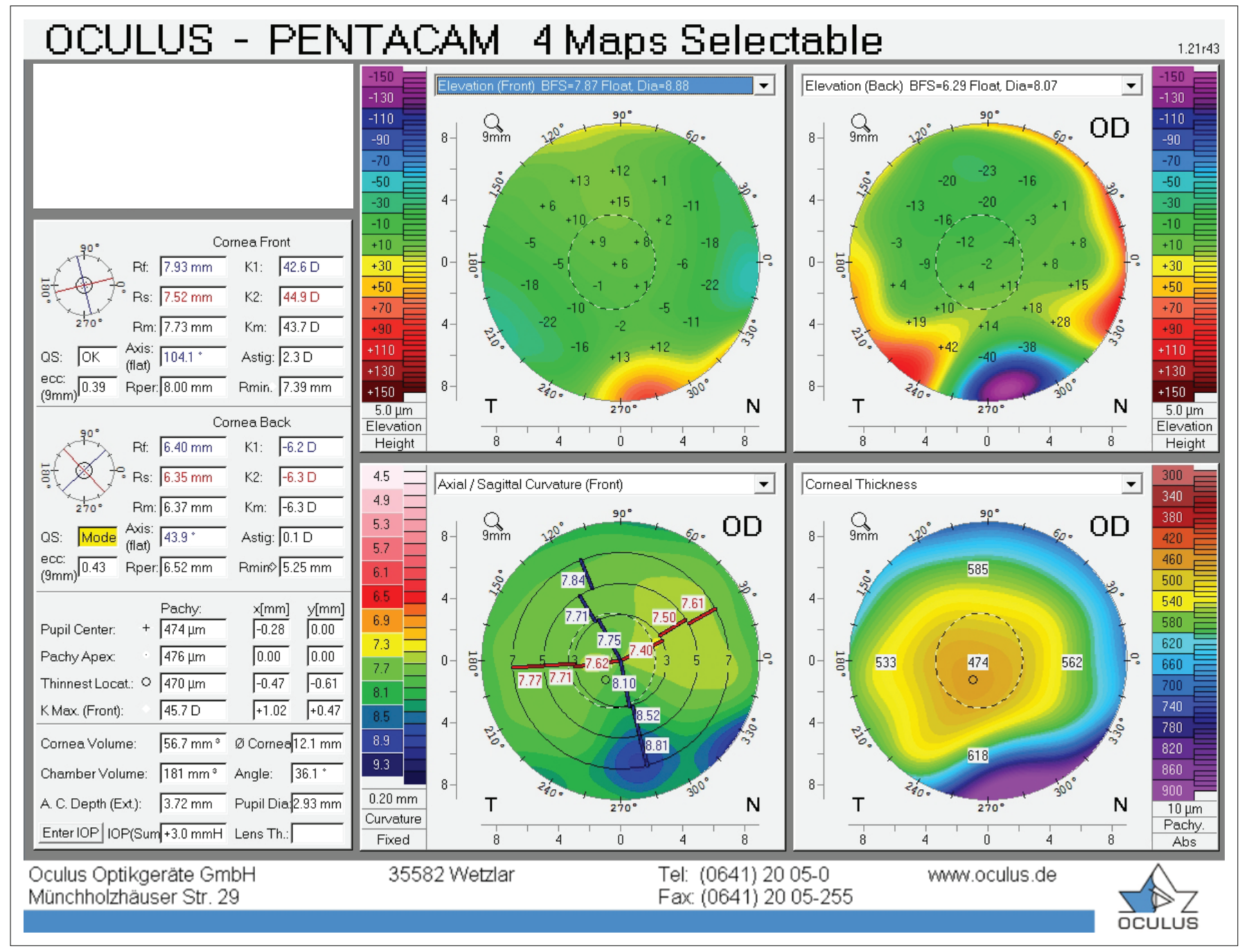

Source: Scan courtesy of Roland Hollhumer.

OD, Oculus dexter.

FIGURE 2: Pentacam scan of the right eye. Note the topographic changes extending well into the corneal stroma. 


\section{Acknowledgements}

\section{Competing interests}

The authors have declared that no competing interests exist.

\section{Authors' contributions}

All authors contributed equally to this work.

\section{Ethical considerations}

This article followed all necessary ethical standards.

\section{Funding information}

This research received no specific grant from any funding agency in the public, commercial or not-for-profit sectors.

\section{Data availability statement}

Data sharing is not applicable to this article as no new data were created or analysed in this study.

\section{Disclaimer}

The views and opinions expressed in this article are those of the authors and do not necessarily reflect the official policy or position of any affiliated agency of the authors.

\section{References}

1. Maust HA, Raber IM. Peripheral hypertrophic subepithelial corneal degeneration Eye Contact Lens. 2003;29(4):266-269. https://doi.org/10.1097/01.icl.0000087489. 61955.82

2. Gore DM, Lovieno A, Connell BJ, Alexander R, Meligonis G, Dart JK. Peripheral hypertrophic subepithelial corneal degeneration: Nomenclature, phenotypes, and long-term outcomes. Ophthalmology. 2013;120(5):892-898. https://doi.org/ 10.1016/j.ophtha.2012.10.037

3. Jeng BH, Millstein ME. Reduction of hyperopia and astigmatism after superficial keratectomy of peripheral hypertrophic subepithelial corneal degeneration. Eye Contact Lens. 2006;32(3):153-156. https://doi.org/10.1097/01.icl.0000182875. 61214.cf

4. Das S, Link B, Seitz B. Salzmann's nodular degeneration of the cornea: A review and case series. Cornea. 2005;24(7):772-777. https://doi.org/10.1097/01.ico. 0000153100.74033.ef

5. Maharana PK, Sharma N, Das S, et al. Salzmann's nodular degeneration. Ocul Surf. 2016;14(1):20-30. https://doi.org/10.1016/j.jtos.2015.08.006

6. Farjo AA, Halperin GI, Syed N, Sutphin JE, Wagoner MD. Salzmann's nodular corneal degeneration clinical characteristics and surgical outcomes. Cornea. 2006;25(1):11-15. https://doi.org/10.1097/01.ico.0000167879.88815.6b 